Available online on 15.11.2020 at http://jddtonline.info
Open Access to Pharmaceutical and Medical Research
unrestricted non-commercial use, provided the original work is properly cited

Open $\odot$ Access

\title{
Potential Drug-Drug and Drug-Disease interactions of selected experimental therapies used in treating COVID-19 patients
}

\author{
Radhwan Nidal Al-Zidan \\ Department of Pharmaceutics, College of Pharmacy, University of Mosul, Iraq
}

\begin{abstract}
At the end of 2019, the whole world was witnessing the birth of a new member of the Severe Acute Respiratory Syndrome Coronavirus 2 (SARS-CoV-2) family in Wuhan city, China. Since then, the 2019 novel coronavirus (COVID-19) has rapidly invaded every corner of the world Before the end of September 2020, nearly 32 million cases worldwide were recorded, with a death toll of approximately 1 million cases. As COVID-19 has spread across the world, certain groups of people prove more susceptible than others. Elderly patients and people with chronic medical conditions such as heart disease or diabetes are more likely to experience or even suffer from serious diseases. As a population, senior citizens take more medicines than young people. Similarly, people with chronic illnesses who are several taking drugs to control their illness. All this poses a significant query in managing COVID-19 cases: can a standard drug regimen be paired with one or more experimental drugs? For example, some of the most widely prescribed medicines-including antibacterial drugs, antifungals, heart-related medications, neuroleptics, contraceptives, and sedatives - can have extensive and often even severe interactions with some of the experimental COVID-19 therapy. Therefore, to reduce the morbidity and mortality rate associated with COVID-19, this issue needs to be answered in detail. This review addressed the key points related to the drug-drug and drug-disease interaction in patients with COVID-19. To help health care providers locate the answers they need in the shortest possible time, the information contained in this review has been included in easy-to-read tables.
\end{abstract}

Keywords: Drug interactions; DDIs; Polypharmacy; SARS-CoV-2; COVID-19.

Article Info: Received 11 Sep 2020; $\quad$ Review Completed 21 Oct 2020; $\quad$ Accepted 29 Oct 2020; Available online 15 Nov 2020

Cite this article as:

Al-Zidan RN, Potential Drug-Drug and Drug-Disease interactions of selected experimental therapies used in treating COVID-19 patients, Journal of Drug Delivery and Therapeutics. 2020; 10(6):219-230 http://dx.doi.org/10.22270/jddt.v10i6.4383

*Address for Correspondence:

Radhwan Nidal Al-Zidan (B.Sc. Pharm, M.Sc. Med. Biotech), Department of Pharmaceutics, College of Pharmacy, University of Mosul, Iraq

\section{Introduction}

Interactions between drugs could be described as the combination of two perhaps even more drugs, so that one drug's potency, sometimes even efficacy, is substantially altered by the existence of another medication. Adverse drug reactions (ADIs) well-documented causes of increasing patient morbidity as well as rising medical costs and complaints of malpractice. ${ }^{1}$ Generally, drug interactions are known to include the effect(s) of one drug on the disposition and/or response to another. Normally such associations are addressed in pharmacokinetics-in which one medication alters the absorption, distribution, metabolism, or elimination (ADME) of another drug and pharmacodynamics-in which one medication affects the response to another medication (apart from the pharmacokinetic effects). ${ }^{2}$ The effect of a patient's condition on the disposition and reaction to a medication is of equal significance.3Moreover, many medications adversely interfere with a variety of diseases, and vice versa. (i.e. drug- disease interactions). Unfortunately, this point has been scarcely addressed. Therefore, in addition to examining interactions between medications, this review also discusses interactions between the disease(s) and the experimental drugs used in COVID-19. An expanding number of studies have suggested that there is significant potential for ADIs occurrence in patients with COVID-19.4 Moreover, since the start of COVID-19 pandemic numerous studies and clinical trials, continuously, suggest the use of an even increasing number of potential and adjuvant drugs. ${ }^{5}$ Therefore, it is necessary to provide the healthcare providers with a comprehensive resource that contain all the possible drugdrug and drug-disease interaction in patients treated for COVID-19.

Currently, more than 200 thousand people are being infected with COVID-19 each day-worldwide. ${ }^{6}$ This extremely high number of cases is a huge burden on the healthcare personnel; therefore, the healthcare professionals may not have the sufficient time to go through all the relevant articles 
published about the safety of medications used in patients with COVID-19. That is why in this review all the information related to the drug-drug interactions as well as the drug- disease interactions was organized in easy-to-read comprehensive tables, as shown below in tables $1 \& 2$.

Table 1: Drug-Drug interactions of selected experimental therapies for COVID-19

\begin{tabular}{|c|c|c|c|}
\hline $\begin{array}{l}\text { Class of } \\
\text { Druggs }\end{array}$ & Drug & prug-Drug Interactions & Notes \\
\hline \multirow{4}{*}{ 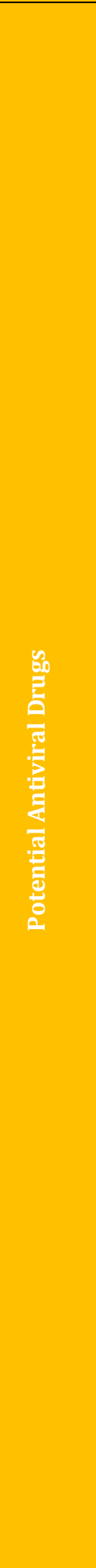 } & 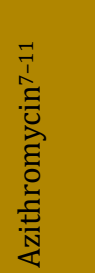 & $\begin{array}{l}\text { - Azithromycin stretches the QT interval, which raises the risk of } \\
\text { developing cardiac arrhythmia and torsades de pointes. } \\
\text { - Digoxin, diltiazem can prolong the PR interval and azithromycin has } \\
\text { been shown to prolong the QT interval. } \\
\text { - Azithromycin may potentiate the effects of oral anticoagulants. }\end{array}$ & $\begin{array}{l}\text { Clinical monitoring, and likely } \\
\text { serum digoxin levels, are } \\
\text { recommended during and } \\
\text { after azithromycin therapy is } \\
\text { discontinued. }\end{array}$ \\
\hline & 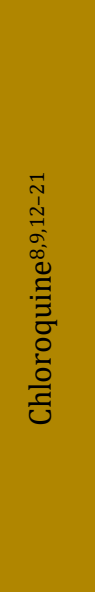 & $\begin{array}{l}\text { - Chloroquine increases the hazard of prolonged QT interval in } \\
\text { patients with COVID-19 who is also using Azithromycin. } \\
\text { - Chloroquine enhances the pharmacodynamic action of the oral } \\
\text { hypoglycemic drugs and Increases the risk of hypoglycemia. } \\
\text { - Chloroquine is a moderate inhibitor of CYP2D6. Therefore, } \\
\text { chloroquine could raise the serum concentrations of risperidone, } \\
\text { metoprolol, aripiprazole, iloperidone, haloperidol, Tricyclic } \\
\text { Antidepressants, fluoxetine, and paroxetine. On the contrary. } \\
\text { Chloroquine will reduce the serum level of the prodrugs that are } \\
\text { dependent on CYP2D6 for their activation. For instance, Tramadol } \\
\text { and Codeine. } \\
\text { - Chloroquine is an inhibitor of the transport system P-glycoprotein } \\
\text { (P-gp). Therefore, Chloroquine is expected to rise the serum level of } \\
\text { the cyclosporine. }\end{array}$ & \\
\hline & 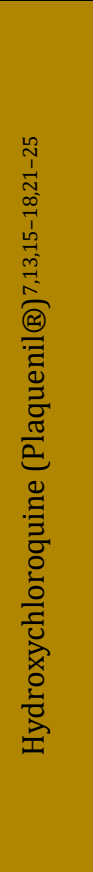 & $\begin{array}{l}\text { - Hydroxychloroquine decreases metabolism of beta-blockers such as } \\
\text { carvedilol and metoprolol. } \\
\text { - Hydroxychloroquine is an inhibitor of the transport system (P-gp). } \\
\text { Therefore, increases the serum level of the substrates of this cellular } \\
\text { pump inhibitor (such as cyclosporine and digoxin). } \\
\text { - Hydroxychloroquine increases the risk of prolonged QT interval in } \\
\text { patients with COVID-19 who is also using Azithromycin. } \\
\text { - Hydroxychloroquine potentiates the effect of other medications that } \\
\text { lengthen the QTc interval (e.x. Azithromycin \& Domperidone). } \\
\text { - Hydroxychloroquine enhances the pharmacodynamic action of the } \\
\text { oral hypoglycemic drugs and Increases the risk of hypoglycemia. } \\
\text { - Hydroxychloroquine is a moderate inhibitor of CYP2D6. Therefore, } \\
\text { chloroquine could raise the serum concentrations of risperidone, } \\
\text { metoprolol, aripiprazole, iloperidone, haloperidol, Tricyclic } \\
\text { Antidepressants, fluoxetine, and paroxetine. On the contrary. } \\
\text { Chloroquine will reduce the serum level of the prodrugs that are } \\
\text { dependent on CYP2D6 for their activation. For instance, Tramadol } \\
\text { and Codeine. } \\
\text { - The risk of peripheral neuropathy may be increased if } \\
\text { Hydroxychloroquine used concurrently with tocilizumab. }\end{array}$ & $\begin{array}{l}\text { QT monitoring may be } \\
\text { required. }\end{array}$ \\
\hline & 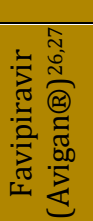 & $\begin{array}{l}\text { - Coadministration of paracetamol and favipiravir increases } \\
\text { paracetamol } \mathrm{C}_{\max } \text { and AUC. } \\
\text { - Coadministration of theophylline and favipiravir increases } \\
\text { favipiravir } C_{\max } \text { and AUC. }\end{array}$ & $\begin{array}{l}\text { In adults, the average dosage } \\
\text { of paracetamol does not } \\
\text { exceed } 3 \mathrm{~g} / \text { day (rather than } 4 \\
\text { g/day). }\end{array}$ \\
\hline
\end{tabular}




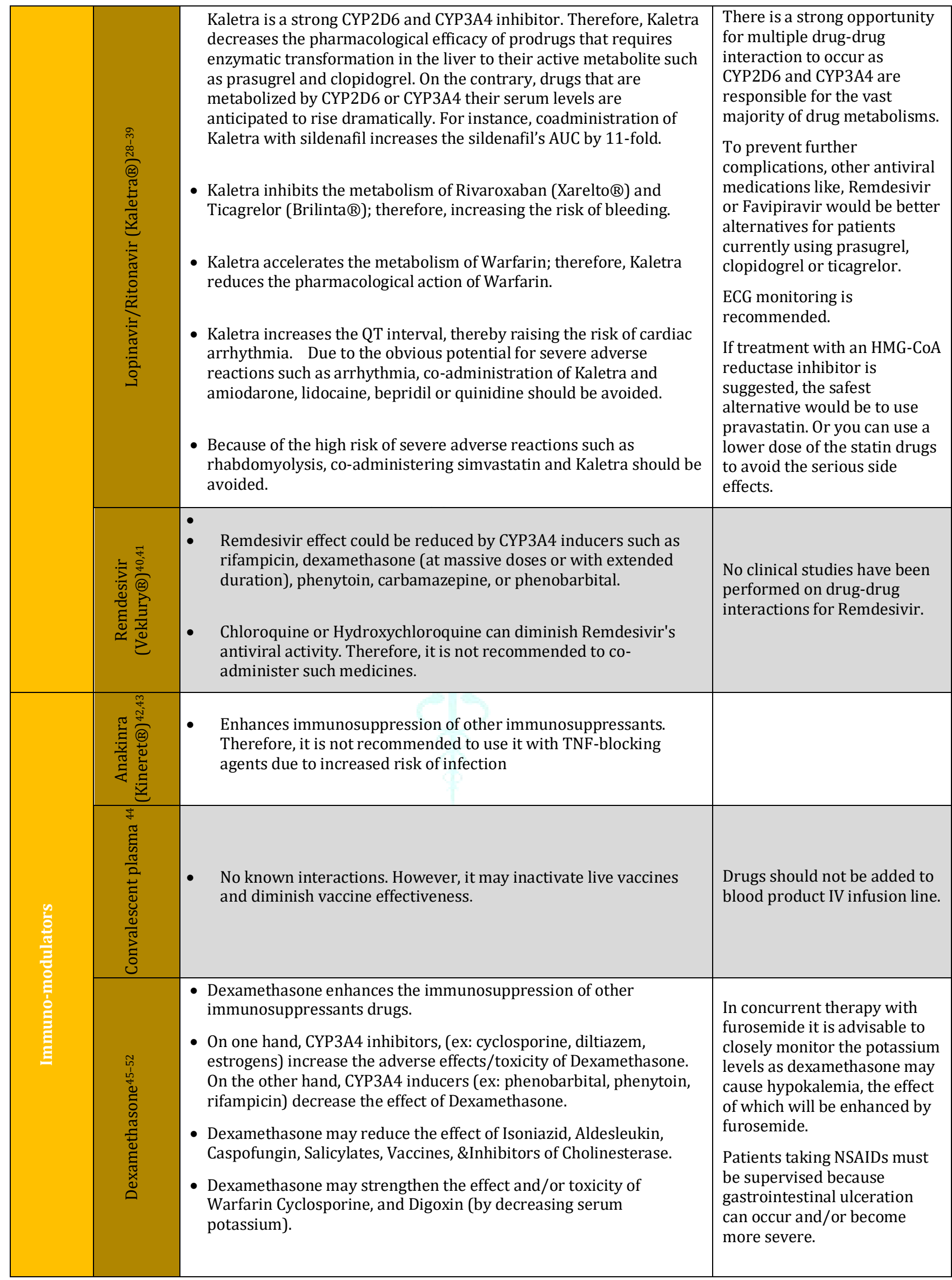




\begin{tabular}{|c|c|c|c|}
\hline & 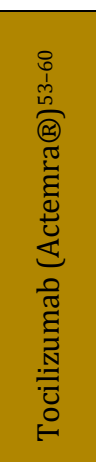 & $\begin{array}{l}\text { - May increase CYP450 enzyme activity. Therefore, it could decrease } \\
\text { the serum levels of many medications thar are metabolized by the } \\
\text { CYP450, such as Simvastatin. } \\
\text { - The risk of peripheral neuropathy may be increased during } \\
\text { concurrent use with hydroxychloroquine. } \\
\text { - Coadministration of tocilizumab with immunosuppressive disease- } \\
\text { modifying antirheumatic drug DMARDs (such as Leflunomide Or } \\
\text { Methotrexate) or corticosteroids may lead to serious infections. }\end{array}$ & $\begin{array}{l}\text { Concurrent therapy } \\
\text { monitoring is required for the } \\
\text { CYP450-metabolized drugs. } \\
\text { Patients should be closely } \\
\text { monitored for signs of } \\
\text { neuropathy in the feet and } \\
\text { hands, such as swelling, } \\
\text { tingling, discomfort or } \\
\text { numbness. } \\
\text { Avoid concomitant use of } \\
\text { DMARDs with tocilizumab. }\end{array}$ \\
\hline & 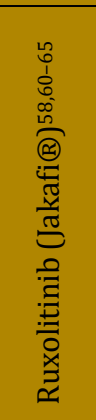 & $\begin{array}{l}\text { - Using rivaroxaban together with Ruxolitinib can increase the risk of } \\
\text { bleeding, including severe and occasionally fatal hemorrhage. } \\
\text { - When Ruxolitinib administered with strong CYP3A4 inhibitors such } \\
\text { as Ketoconazole, Fluconazole, And Erythromycin dose modifications } \\
\text { is required. } \\
\text { - Coadministration of Ruxolitinib with immunosuppressive disease- } \\
\text { modifying antirheumatic drug DMARDs (such as leflunomide or } \\
\text { methotrexate) or immunosuppressive agents (high-dose } \\
\text { corticosteroids, tofacitinib, basiliximab, and mycophenolic acid) may } \\
\text { lead to serious infections along with lymphoma. }\end{array}$ & \\
\hline & 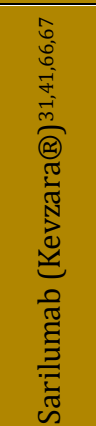 & $\begin{array}{l}\text { Using sarilumab together with adalimumab, baricitinib, etanercept, } \\
\text { infliximab, may intensify the hazard of serious and potentially life- } \\
\text { threatening infections. } \\
\text { - Sarilumab may increase CYP450 enzyme activity. Therefore, it could } \\
\text { decrease blood concentration \& efficacy of many drugs thar are } \\
\text { metabolized by the CYP450, such as Simvastatin, atorvastatin, } \\
\text { amiodarone, diazepam, sildenafil, vardenafil, tadalafil, vinblastine, } \\
\text { nifedipine, phenytoin, quinidine, alprazolam, theophylline, } \\
\text { methylprednisolone, and dexamethasone. }\end{array}$ & $\begin{array}{l}\text { Effects of Sarilumab on } \\
\text { CYP } 450 \text { can continue for } \\
\text { weeks following its } \\
\text { discontinuation. }\end{array}$ \\
\hline \multirow{4}{*}{ 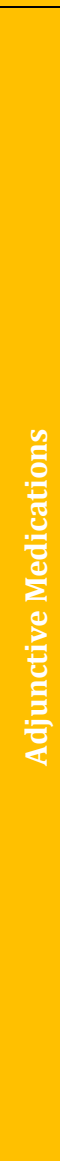 } & 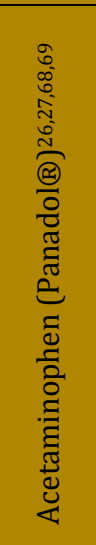 & $\begin{array}{l}\text { - Coadministration of paracetamol and favipiravir increases } \\
\text { paracetamol } C_{\max } \text { and AUC. } \\
\text { - Doses of Acetaminophen greater than } 1.3 \text { gm / day could enhance } \\
\text { the anticoagulant activity of warfarin and increases the risk of } \\
\text { bleeding. }\end{array}$ & $\begin{array}{l}\text { The daily dose of paracetamol } \\
\text { in adults should be no more } \\
\text { than } 3000 \mathrm{mg} / \text { day (rather } \\
\text { than } 4000 \mathrm{mg} \text { /day) when } \\
\text { given with favipiravir. } \\
\text { Patients with hepatic } \\
\text { impairment may be at } \\
\text { increased risk of toxicity. } \\
\text { Close monitoring is } \\
\text { mandatory in patients } \\
\text { concurrently using } \\
\text { medications well-known to } \\
\text { induce hepatotoxicity such as } \\
\text { Remdesivir. }\end{array}$ \\
\hline & 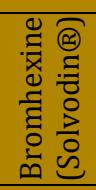 & $\begin{array}{l}\text { - No clinically important unfavorable interactions have been reported } \\
\text { with other medicines. }\end{array}$ & \\
\hline & 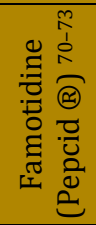 & $\begin{array}{l}\text { - Famotidine significantly increases the anticoagulant activity of } \\
\text { warfarin and intensify the hazard of bleeding. } \\
\text { - Famotidine reduces the hepatic metabolism of chloroquine, } \\
\text { theophylline, phenytoin, propranolol, and lidocaine. }\end{array}$ & $\begin{array}{l}\text { Adjustment of the warfarin } \\
\text { dose may be necessary }\end{array}$ \\
\hline & 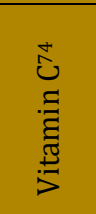 & $\begin{array}{l}\text { - Affects the excretion of drugs which are weak acids or bases can be } \\
\text { diminished or increased, respectively. For instance, fluphenazine \& } \\
\text { Amphetamine are well-known examples for such interaction. } \\
\text { - Vitamin C may reduce the anticoagulant activity of warfarin, and } \\
\text { cyclosporine. }\end{array}$ & \\
\hline
\end{tabular}




\begin{tabular}{|c|c|c|}
\hline 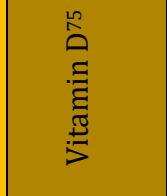 & $\begin{array}{l}\text { - Taking digoxin together with vitamin D can boost the effects of } \\
\text { digoxin and lead to arrhythmia. } \\
\text { - Taking large quantities of vitamin D along with diltiazem may } \\
\text { reduce the efficacy of diltiazem. }\end{array}$ & \\
\hline 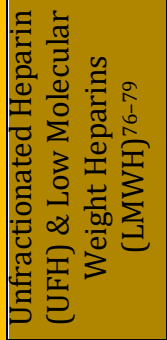 & $\begin{array}{l}\text { - UFH: increased risk of bleeding with other anticoagulants, } \\
\text { antiplatelets, NSAIDs. } \\
\text { - IV nitroglycerin may reduce heparin's anticoagulant effect. } \\
\text { - LMWH: increased risk of bleeding with other anticoagulants, } \\
\text { antiplatelets, NSAIDs. }\end{array}$ & \\
\hline 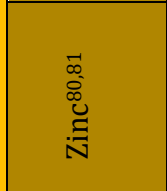 & $\begin{array}{l}\text { - Zinc reduces the absorption of Quinolone \&Tetracycline antibiotics } \\
\text { (such as, Ciprofloxacin, Gatifloxacin, Moxifloxacin, Levofloxacin, } \\
\text { Minocycline and Tetracycline). In addition, Zinc is implicated in } \\
\text { hindering the absorption of other antibiotics-for instance, } \\
\text { Cephalexin. }\end{array}$ & $\begin{array}{l}\text { The doses used for COVID-19 } \\
\text { in registered clinical trials } \\
\text { differ among studies, with a } \\
\text { maximum dose of } 50 \mathrm{mg} \\
\text { (elemental zinc) twice daily. }\end{array}$ \\
\hline
\end{tabular}

Table 2: Drug-Disease interactions of selected experimental therapies for COVID-19

\begin{tabular}{|c|c|c|c|}
\hline $\begin{array}{l}\text { Class of } \\
\text { Drugs }\end{array}$ & Drug & Drug-Disease Interactions & Notes \\
\hline$\frac{a}{b}$ & 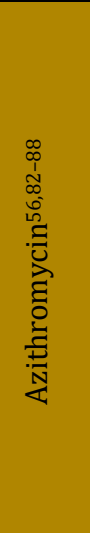 & $\begin{array}{l}\text { - Patients with noninfectious colitis or enteritis are at multiplied hazard of } \\
\text { developing pseudomembranous colitis. } \\
\text { - Azithromycin rises the hazard of prolonged cardiac repolarization and } \\
\text { QT in patients with history of torsades de pointes, elongation of the QT } \\
\text { interval, bradyarrhythmia, congenital-long QT syndrome, patients with } \\
\text { uncorrected hypomagnesemia or hypokalemia, or patients using another } \\
\text { drug that prolongs the QT interval. } \\
\text { - In general, the use of macrolide antibiotics has been reported to worsen } \\
\text { symptoms of myasthenia gravis. }\end{array}$ & $\begin{array}{l}\text { Stool test for C. difficile } \\
\text { toxin and stool cultures } \\
\text { for C. difficile could be } \\
\text { beneficial } \\
\text { diagnostically. } \\
\text { It is suggested to use } \\
\text { ECG to monitor } \\
\text { patients during } \\
\text { therapy. } \\
\text { If signs and symptoms } \\
\text { of hepatitis occur, } \\
\text { Azithromycin should be } \\
\text { stopped immediately. }\end{array}$ \\
\hline 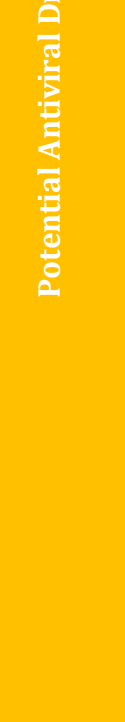 & 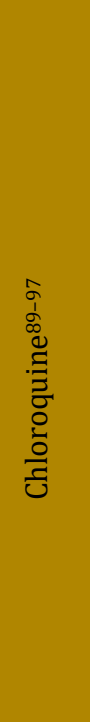 & $\begin{array}{l}\text { - Chloroquine use is commonly considered contraindicated in the presence } \\
\text { of retinal or visual field changes. } \\
\text { - The use of Chloroquine may exacerbate the medical condition in patients } \\
\text { with porphyria. } \\
\text { - Chloroquine rises the risk of elongated cardiac repolarization and QT in } \\
\text { patients with history of torsades de pointes, elongated of the QT interval, } \\
\text { bradyarrhythmia, congenital-long QT syndrome, patients with } \\
\text { uncorrected hypomagnesemia or hypokalemia, or patients using another } \\
\text { drug that prolongs the QT interval. } \\
\text { - Chloroquine may provoke epileptic seizures in prone individuals. } \\
\text { Therefore, patients with low seizure threshold or epilepsy may be at } \\
\text { greater risk. } \\
\text { - Chloroquine may provoke acute renal failure and hemolysis in patients } \\
\text { with glucose } 6 \text { phosphate dehydrogenase (G6PD) deficiency. } \\
\text { - The use of Chloroquine may incite a severe attack of psoriasis. }\end{array}$ & $\begin{array}{l}\text { Chloroquine should be } \\
\text { ceased immediately if } \\
\text { visual abnormalities } \\
\text { (e.g., changes in visual } \\
\text { acuity, loss of foveal } \\
\text { reflex or pigmentary } \\
\text { changes) develop. } \\
\text { It is suggested to use } \\
\text { ECG to monitor } \\
\text { patients during } \\
\text { therapy. } \\
\text { Both of the hemoglobin } \\
\text { and blood cell counts } \\
\text { should be checked } \\
\text { regularly. }\end{array}$ \\
\hline
\end{tabular}




\begin{tabular}{|c|c|c|c|}
\hline & 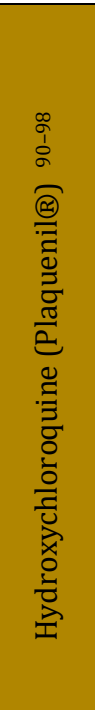 & $\begin{array}{l}\text { - Hydroxychloroquine use is commonly considered contraindicated in } \\
\text { the presence of retinal or visual field changes.. } \\
\text { The use of Hydroxychloroquine may exacerbate the medical condition } \\
\text { in patients with porphyria. } \\
\text { Hydroxychloroquine rises the risk of elongated cardiac repolarization } \\
\text { and QT in patients with history of torsades de pointes, elongated of the } \\
\text { QT interval, bradyarrhythmia, congenital-long QT syndrome, patients } \\
\text { with uncorrected hypomagnesemia or hypokalemia, or patients using } \\
\text { another drug that prolongs the QT interval. } \\
\text { Hydroxychloroquine may provoke epileptic seizures in prone } \\
\text { individuals. Therefore, patients with low seizure threshold or epilepsy } \\
\text { may be at greater risk. } \\
\text { Hydroxychloroquine may provoke acute renal failure and hemolysis in } \\
\text { patients with glucose } 6 \text { phosphate dehydrogenase (G6PD) deficiency. } \\
\text { The use of Hydroxychloroquine may incite a severe attack of psoriasis. }\end{array}$ & $\begin{array}{l}\text { Chloroquine should be } \\
\text { ceased immediately if } \\
\text { visual abnormalities } \\
\text { (e.g., changes in visual } \\
\text { acuity, loss of foveal } \\
\text { reflex or pigmentary } \\
\text { changes) develop. } \\
\text { It is suggested to use } \\
\text { ECG to monitor } \\
\text { patients during } \\
\text { therapy. } \\
\text { Both of the hemoglobin } \\
\text { and blood cell counts } \\
\text { should be checked } \\
\text { regularly. }\end{array}$ \\
\hline & 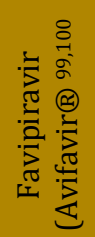 & $\begin{array}{l}\text { - It is better to be avoided in patients with severely impaired renal or } \\
\text { hepatic function }\end{array}$ & \\
\hline & 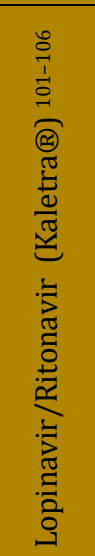 & $\begin{array}{l}\text { - Lopinavir/Ritonavir is a known hepatotoxic. Therefore, Kaletra is } \\
\text { better to be avoided in patients with hepatic impairment. } \\
\text { - } \begin{array}{l}\text { Patients with hemophilia are at an increased hazard of bleeding when } \\
\text { given Lopinavir/Ritonavir. }\end{array} \\
\text { - Lopinavir/Ritonavir has been reported to elevate the blood glucose } \\
\text { level. Therefore, it should be used with caution in patients with } \\
\text { Diabetes Mellitus. } \\
\text { - Second and third degree atrioventricular (AV) block have been } \\
\text { reported with the use of Ritonavir. Therefore, in patients with pre- } \\
\text { existing conduction irregularities, underlying heart disease, ischemic } \\
\text { heart disease, or cardiomyopathies, Kaletra should be cautiously } \\
\text { prescribed because such patients are at greater risk for developing } \\
\text { cardiac conduction abnormalities. }\end{array}$ & \\
\hline & 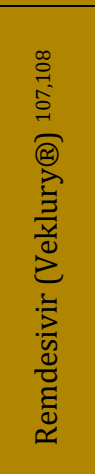 & $\begin{array}{l}\text { The use of Remdesivir has been associated with Transaminase } \\
\text { elevations in patients with COVID-19 and healthy volunteers. } \\
\text { Therefore, Remdesivir should be used with caution in patients with } \\
\text { hepatic impairment. }\end{array}$ & $\begin{array}{l}\text { Hepatic laboratory } \\
\text { testing is crucial at } \\
\text { baseline and on daily } \\
\text { basis during } \\
\text { Remdesivir } \\
\text { administration. } \\
\text { Stop Remdesivir if the } \\
\text { level of Alanine } \\
\text { Aminotransferase ( } \\
\text { ALT) becomes more } \\
\text { than } 5 \text { times the upper } \\
\text { limit of normal (ULN). }\end{array}$ \\
\hline 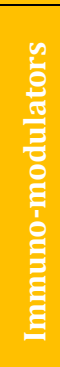 & 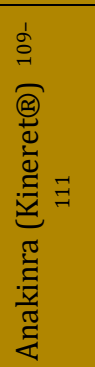 & $\begin{array}{l}\text { - Anakinra impedes the immune response. Therefore, Anakinra should } \\
\text { not be given to patients with active infections or those who acquire } \\
\text { severe infections after administration of Anakinra. } \\
\text { - Anakinra is mainly excreted by the kidneys. Therefore, in patients with } \\
\text { renal dysfunction it should be used with vigilance to prevent toxic } \\
\text { reactions. } \\
\text { Anakinra should be used with vigilance in patients with hepatic } \\
\text { diseases. }\end{array}$ & $\begin{array}{l}\text { Patients with severe } \\
\text { renal dysfunction or } \\
\text { end-stage renal disease } \\
\text { should receive the dose } \\
\text { of Anakinra every other } \\
\text { day. } \\
\text { Monitoring of renal } \\
\text { function is } \\
\text { recommended. }\end{array}$ \\
\hline
\end{tabular}




\begin{tabular}{|c|c|c|c|}
\hline & 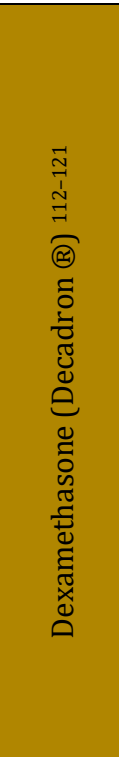 & $\begin{array}{l}\text { - Dexamethasone might cause gastrointestinal hemorrhage and } \\
\text { perforation. Therefore, Dexamethasone should be carefully } \\
\text { administered or avoided in patients with ulcerative colitis, bowel } \\
\text { anastomosis or diverticulitis. } \\
\text { - Dexamethasone impedes the immune response. Therefore, } \\
\text { Dexamethasone should not be commenced in actively infected patients } \\
\text { or those who develop serious infections after its administration. } \\
\text { - Dexamethasone can elevate blood glucose level by suppressing the } \\
\text { secretion and antagonizing the action of insulin, which leads to } \\
\text { augmented gluconeogenesis and suppression of peripheral glucose } \\
\text { uptake. Therefore, Dexamethasone should be used with attentiveness } \\
\text { in patients with Diabetes Mellitus. } \\
\text { Dexamethasone is mostly metabolized in the liver and may have higher } \\
\text { pharmacological actions in patients with hepatic disease. } \\
\text { The use of dexamethasone in patients recently recovered from } \\
\text { myocardial infarction can be related to left ventricular free-wall } \\
\text { rupture. Hence, Dexamethasone should be used with extreme caution } \\
\text { in myocardial infarction. }\end{array}$ & $\begin{array}{l}\text { Dosage adjustments } \\
\text { might be needed in } \\
\text { patients with liver } \\
\text { disease. }\end{array}$ \\
\hline & 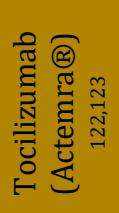 & $\begin{array}{l}\text { Tocilizumab impedes the immune response. Therefore, Tocilizumab } \\
\text { should not be commenced in actively infected patients or those who } \\
\text { develop serious infections after its administration. } \\
\text { - Tocilizumab should be avoided or administered with great } \\
\text { attentiveness in patients with hepatic impairment. }\end{array}$ & \\
\hline & 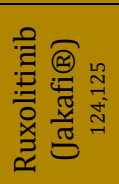 & $\begin{array}{l}\text { Ruxolitinib impedes the immune response. Therefore, it should not be } \\
\text { started in patients with active infections or those who develop serious } \\
\text { infections after Ruxolitinib administration. }\end{array}$ & $\begin{array}{l}\text { Dose adjustment is } \\
\text { required in patients } \\
\text { with renal impairment. }\end{array}$ \\
\hline & 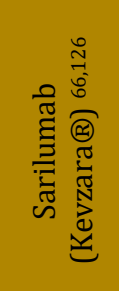 & $\begin{array}{l}\text { - Sarilumab may increase the risk of potentially life-threatening } \\
\text { infections. Therefore, it should not be started in patients with active } \\
\text { infections or those who develop serious infections after Sarilumab } \\
\text { administration. } \\
\text { - Sarilumab is associated with transaminase elevations. Therefore, } \\
\text { Sarilumab is not advised for patients with hepatic impairment or active } \\
\text { liver disease. }\end{array}$ & \\
\hline \multirow{4}{*}{ 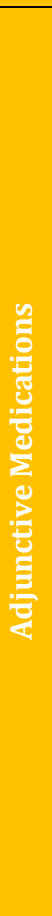 } & 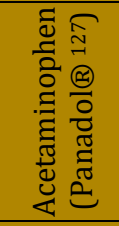 & $\begin{array}{l}\text { Acetaminophen must be used cautiously in patients with hepatic } \\
\text { impairment. }\end{array}$ & \\
\hline & 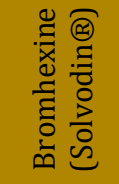 & $\begin{array}{l}\text { No clinically important unfavorable interactions have been reported with } \\
\text { other medicines. }\end{array}$ & \\
\hline & 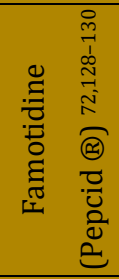 & $\begin{array}{l}\text { Famotidine should be used with caution in patients with impaired kidney } \\
\text { function. }\end{array}$ & $\begin{array}{l}\text { Adjustment of the dose } \\
\text { is important in patients } \\
\text { with renal impairment. }\end{array}$ \\
\hline & 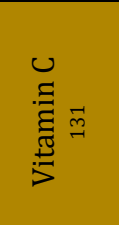 & - Vitamin C should be used vigilantly in patients with G 6 PD. & $\begin{array}{l}\text { It is worth mentioning } \\
\text { that high circulating } \\
\text { concentrations of } \\
\text { vitamin C can affect the } \\
\text { accuracy of } \\
\text { glucometers. }\end{array}$ \\
\hline
\end{tabular}




\begin{tabular}{|c|c|c|}
\hline 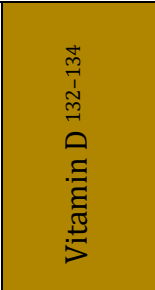 & $\begin{array}{l}\text { Vitamin D functions to increase the serum calcium concentration and } \\
\text { can make arrhythmias worse, especially in patients taking digoxin. } \\
\text { Therefore, high doses of vitamin D should be used cautiously in } \\
\text { patients with arrhythmias. } \\
\text { In the presence of hyperphosphatemia, Vitamin D administration may } \\
\text { lead to the precipitation of calcium-phosphate deposits within the } \\
\text { renal or vascular systems. }\end{array}$ & $\begin{array}{l}\text { Serum concentration of } \\
\text { electrolytes should be } \\
\text { corrected before } \\
\text { initiating vitamin D } \\
\text { therapy. }\end{array}$ \\
\hline 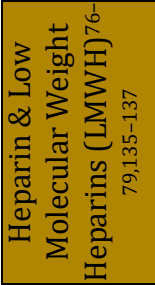 & $\begin{array}{l}\text { Heparin \& Low Molecular Weight Heparins (LMWH) significantly increases } \\
\text { the risk of bleeding in patients suffering from hemophilia, severe liver } \\
\text { disease, hypertensive or diabetic retinopathy, subacute bacterial } \\
\text { endocarditis, or severe renal impairment. }\end{array}$ & \\
\hline 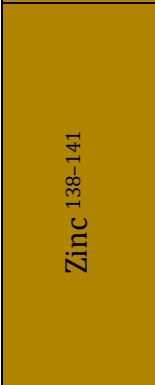 & $\begin{array}{l}\text { The trace metals, chromium and zinc, are excreted primarily in the } \\
\text { urine. Supplemental doses of zinc may need to be reduced, or adjusted } \\
\text { in patients with renal impairment. } \\
\text { Malabsorption syndromes reduce the amount of absorbed zinc. } \\
\text { Therefore, larger dosages may be needed when zinc is given orally. } \\
\text { Long-term zinc intake may cause copper deficiency with associated } \\
\text { reversible hematological defects (i.e., leukopenia, anemia) and possibly } \\
\text { permanent neurological implications (i.e., paresthesia, myelopathy, } \\
\text { spasticity, and ataxia). }\end{array}$ & \\
\hline
\end{tabular}

\section{Discussion}

Comorbid patients need several pharmacological treatments, which in turn may lead to issues that physicians are expected to handle rapidly by recognizing potential drug-drug interactions that could arise in order to prevent diminished efficacy or increased adverse event burden. ${ }^{142}$ To put simply, the issue of whether concurrent pharmacological therapies that compromise patient safety is typically answered in a context that recognizes the treatment choices for each particular disease, enabling reasonable handling of interactions based on reliable clinical evidence. ${ }^{143}$ However, in the case of comorbid conditions happening in COVID-19 patients, healthcare professionals now are needed to consider the hard question as to whether interactions between COVID-19 pharmacological treatments, which are not yet well-defined, and various therapeutic agents are possible. ${ }^{144}$ Moreover, while waiting for the results from more than 300 ongoing clinical trials aimed at identifying successful treatments against the COVID-19 virus, how drugs used in COVID-19 patients (e.g., various Antiviral Agents, Azithromycin, Hydroxychloroquine, and Monoclonal
Antibodies) that redundantly disturb the pharmacodynamics and pharmacokinetics of other drugs, and vice versa, remains a topic of investigation.4,145Therefore, focus is put on the interactions between the medications most widely used for COVID-19 and various classes of medications (Table 1) and the most important drug-disease interaction in (Table 2).

Given the range of potential interactions with hepatic metabolism systems, such as Cytochromes P450 (CYPs), as most of the existing antiviral medications used in COVID-19 infection are expected to affect various CYP450 isozymes. Therefore, dose adjustments may be needed. Some of the most challenging drug-drug interactions are between investigational COVID-19 medicines and cardiovascular medicines, including anti-arrhythmias, beta-blockers, calcium channel blockers, anti-coagulants, and lipid-lowering statins. Antibacterial medications are another significant class; many have a defined effect on the QT interval, and others may alter the level of a COVID-19 drug, a comedication, or both in the body. ${ }^{146,147}$ For instance, Rifampicin, can reduce the serum level of the experimental COVID-19 medication ritonavir/lopinavir by $75 \%$. 148 


\section{References}

1 Jagadeesan M, Manikandan R, Sudha NSS. The drug-drug interactions: Affecting the rationality of prescriptions. Research Journal of Pharmacy and Technology 2018; 11:3077-80.

2 Palleria C, di Paolo A, Giofrè C, et al. Pharmacokinetic drugdrug interaction and their implication in clinical management. Journal of Research in Medical Sciences. 2013; 18:600-9.

3 Kafeel H, Rukh R, Qamar H, et al. Possibility of Drug-Drug Interaction in Prescription Dispensed by Community and Hospital Pharmacy. Pharmacology \&amp; Pharmacy 2014; 05:401-7.

4 Back D, Marzolini C, Hodge C, et al. COVID-19 treatment in patients with comorbidities: Awareness of drug-drug interactions. British Journal of Clinical Pharmacology. 2020. DOI:10.1111/bcp.14358.

$5 \quad$ Patil PA, Jain RitikS. Theoretical Study and treatment of Novel COVID-19. Research Journal of Pharmacology and Pharmacodynamics 2020; 12:71.

6 Worldometer. Coronavirus Cases. Worldometer 2020; 1 22.

7 Gautret P, Lagier JC, Parola P, et al. Hydroxychloroquine and azithromycin as a treatment of COVID-19: results of an open-label non-randomized clinical trial. International Journal of Antimicrobial Agents 2020; 56. DOI:10.1016/j.ijantimicag.2020.105949.

8 Saleh M, Gabriels J, Chang D, et al. Effect of Chloroquine, Hydroxychloroquine, and Azithromycin on the Corrected QT Interval in Patients with SARS-CoV-2 Infection. Circulation: Arrhythmia and Electrophysiology 2020; 13:496-504.

9 Nachimuthu S, Assar MD, Schussler JM. Drug-induced QT interval prolongation: Mechanisms and clinical management. Therapeutic Advances in Drug Safety. 2012; 3:241-53.

10 Sears SP, Getz TW, Austin CO, Palmer WC, Boyd EA, Stancampiano FF. Incidence of Sustained Ventricular Tachycardia in Patients with Prolonged QTc After the Administration of Azithromycin: A Retrospective Study. Drugs - Real World Outcomes 2016; 3:99-105.

11 Glasheen JJ, Fugit R v., Prochazka A v. The risk of overanticoagulation with antibiotic use in outpatients on stable warfarin regimens. Journal of General Internal Medicine 2005; 20:653-6.

12 Smit C, Peeters MYM, van den Anker JN, Knibbe CAJ. Chloroquine for SARS-CoV-2: Implications of Its Unique Pharmacokinetic and Safety Properties. Clinical Pharmacokinetics 2020; 59:659-69.

13 Mercuro NJ, Yen CF, Shim DJ, et al. Risk of QT Interval Prolongation Associated with Use of Hydroxychloroquine with or without Concomitant Azithromycin among Hospitalized Patients Testing Positive for Coronavirus Disease 2019 (COVID-19). JAMA Cardiology 2020. DOI:10.1001/jamacardio.2020.1834.

14 Bessière $F$, Roccia $H$, Delinière $A$, et al. Assessment of QT Intervals in a Case Series of Patients with Coronavirus Disease 2019 (COVID-19) Infection Treated with Hydroxychloroquine Alone or in Combination with Azithromycin in an Intensive Care Unit. JAMA Cardiology. 2020. DOI:10.1001/jamacardio.2020.1787.

15 Hasler JA, Johansson I, Masimirembwa CM. Inhibitory effects of antiparasitic drugs on cytochrome P450 2D6. European Journal of Clinical Pharmacology 1995; 48:35-8.

16 Gupta A. Real-World Clinical Effectiveness and Tolerability of Hydroxychloroquine $400 \mathrm{Mg}$ in Uncontrolled Type 2 Diabetes Subjects who are not Willing to Initiate Insulin Therapy (HYQ-Real-World Study). Current Diabetes Reviews 2019; 15:510-9.

17 Nampoory MRN, Nessim J, Gupta RK, Johny K v. Drug interaction of chloroquine with ciclosporin [1]. Nephron. 1992; 62:108-9.

18 Juurlink DN. Safety considerations with chloroquine, hydroxychloroquine and azithromycin in the management of SARS-CoV-2 infection. CMAJ. 2020; 192:E450-3.

19 Projean D, Baune B, Farinotti R, et al. In vitro metabolism of chloroquine: Identification of CYP2C8, CYP3A4, and
CYP2D6 as the main isoforms catalyzing Ndesethylchloroquine formation. Drug Metabolism and Disposition 2003; 31:748-54.

20 Johnson MI, Radford H. CYP2D6 Polymorphisms and Response to Codeine and Tramadol. Analgesia \& Resuscitation : Current Research 2016; 05. DOI:10.4172/2324-903x.1000e106.

21 Cazet L, Bulteau S, Evin A, et al. Interaction between CYP2D6 inhibitor antidepressants and codeine: is this relevant? Expert Opinion on Drug Metabolism and Toxicology 2018; 14:879-86.

22 Stevenson A, Kirresh A, Conway S, White L, Ahmad M, Little C. Hydroxychloroquine use in COVID-19: is the risk of cardiovascular toxicity justified? Open heart 2020; 7. DOI:10.1136/openhrt-2020-001362.

23 Rosenberg ES, Dufort EM, Udo T, et al. Association of Treatment with Hydroxychloroquine or Azithromycin with In-Hospital Mortality in Patients with COVID-19 in New York State. JAMA - Journal of the American Medical Association 2020; 323:2493-502.

24 Bonow RO, Hernandez AF, Turakhia M.

Hydroxychloroquine, Coronavirus Disease 2019, and QT Prolongation. JAMA Cardiology. 2020. DOI:10.1001/jamacardio.2020.1782.

25 reviews AG-C diabetes, 2019 undefined. Real-world clinical effectiveness and tolerability of hydroxychloroquine $400 \mathrm{mg}$ in uncontrolled type 2 diabetes subjects who are not willing to initiate insulin therapy. ingentaconnect.com https://www.ingentaconnect.com/content/ben/cdr/2019 /00000015/00000006/art00010 (accessed Aug 25, 2020).

26 Shiraki K, Daikoku T. Favipiravir, an anti-influenza drug against life-threatening RNA virus infections. Pharmacology and Therapeutics. 2020; 209:107512107512.

27 Zhao Y, Harmatz JS, Epstein CR, et al. Favipiravir inhibits acetaminophen sulfate formation but minimally affects systemic pharmacokinetics of acetaminophen. British Journal of Clinical Pharmacology 2015; 80:1076-85.

28 Ancrenaz V, Déglon J, Samer C, et al. Pharmacokinetic Interaction Between Prasugrel and Ritonavir in Healthy Volunteers. Basic and Clinical Pharmacology and Toxicology 2013; 112:132-7.

29 Hughes CA, Tseng A, Cooper R. Managing drug interactions in HIV-infected adults with comorbid illness. CMAJ. 2015; 187:36-43.

30 Hsu A, Granneman GR, Bertz RJ. Ritonavir: Clinical pharmacokinetics and interactions with other anti-HIV agents. Clinical Pharmacokinetics 1998; 35:275-91.

31 Elens L, Langman LJ, Hesselink DA, et al. Pharmacologic Treatment of Transplant Recipients Infected With SARSCoV-2: Considerations Regarding Therapeutic Drug Monitoring and Drug-Drug Interactions. Therapeutic drug monitoring. 2020; 42:360-8.

32 Zeitlinger M, Koch BCP, Bruggemann R, et al. Pharmacokinetics/Pharmacodynamics of Antiviral Agents Used to Treat SARS-CoV-2 and Their Potential Interaction with Drugs and Other Supportive Measures: A Comprehensive Review by the PK/PD of Anti-Infectives Study Group of the European Society of Antimicrobial Agents. Clinical Pharmacokinetics. 2020.

DOI:10.1007/s40262-020-00924-9.

33 fda, cder. KALETRA® (lopinavir/ritonavir) capsules. .

34 Liedtke MD, Rathbun RC. Warfarin-antiretroviral interactions. Annals of Pharmacotherapy. 2009; 43: 322-8.

35 Bates DE, Herman RJ. Carbamazepine toxicity induced by lopinavir/ritonavir and nelfinavir. Annals of Pharmacotherapy 2006; 40: 1190-5.

36 Pecora Fulco P, Zingone MM, Higginson RT. Possible antiretroviral therapy-warfarin drug interaction. Pharmacotherapy 2008; 28:945-9.

37 Hughes CA, Freitas A, Miedzinski LJ. Interaction between lopinavir/ritonavir and warfarin. CMAJ 2007; 177:357-9.

38 Experimental COVID-19 Therapy Combination Lopinavir/Ritonavir Is Implicated in a Complicated Set of Drug-Drug Interactions - Anesthesia Patient Safety 
Foundation. https://www.apsf.org/article/experimentalcovid-19-therapy-combination-lopinavir-ritonavir-isimplicated-in-a-complicated-set-of-drug-druginteractions/ (accessed Aug 26, 2020).

39 Elsby R, Hilgendorf C, Fenner K. Understanding the critical disposition pathways of statins to assess drugdrug interaction risk during drug development: It's not just about OATP1B1. Clinical Pharmacology and Therapeutics. 2012; 92:584-98.

40 Administration D. FACT SHEET FOR HEALTH CARE PROVIDERS EMERGENCY USE AUTHORIZATION (EUA) OF VEKLURY $®$ (remdesivir).

https://www.fda.gov/emergency- (accessed Aug 26, 2020).

41 Lemaitre F, Solas C, Grégoire M, et al. Potential drug-drug interactions associated with drugs currently proposed for COVID-19 treatment in patients receiving other treatments. Fundamental \& Clinical Pharmacology 2020; : fcp.12586.

42 Fda, Cder. Kineret $\AA$ (anakinra) for injection, for subcutaneous use. www.fda.gov/medwatch. (accessed Aug 26, 2020).

43 Bachove I, Chang C. Anakinra and related drugs targeting interleukin-1 in the treatment of cryopyrin-associated periodic syndromes. Open Access Rheumatology: Research and Reviews. 2014; 6:15-25.

44 Wang Y, Zhang Y, Yu Q, Zhu K. Convalescent Plasma Coupled With Medications for the Treatment of a Severe COVID-19 Patient: Drugs Analysis and Pharmaceutical Care Based on the Newly Established Guidelines for COVID-19 Remedy. Frontiers in Pharmacology 2020; 11. DOI:10.3389/fphar.2020.00966.

45 Wong DD, Longenecker RG, Liepman M, Baker S, Lavergne M. Phenytoin-Dexamethasone: A Possible Drug-Drug Interaction. JAMA: The Journal of the American Medical Association. 1985; 254:2062-3.

46 van Matre ET, Satyanarayana G, Page RL, Levi ME, Lindenfeld J, Mueller SW. Pharmacokinetic drug-drug interactions between immunosuppressant and antiinfective agents: Antimetabolites and corticosteroids. Annals of Transplantation. 2018; 23:66-74.

47 Anglicheau D, Flamant M, Schlageter MH, et al. Pharmacokinetic interaction between corticosteroids and tacrolimus after renal transplantation. Nephrology Dialysis Transplantation 2003; 18:2409-14.

48 Chen J, Raymond K. Roles of rifampicin in drug-drug interactions: Underlying molecular mechanisms involving the nuclear pregnane $\mathrm{X}$ receptor. Annals of Clinical Microbiology and Antimicrobials. 2006; 5:3.

49 Hazlewood KA, Fugate SE, Harrison DL. Effect of oral corticosteroids on chronic warfarin therapy. Annals of Pharmacotherapy. 2006; 40:2101-6.

50 Carone L, Oxberry SG, Twycross R, Charlesworth S, Mihalyo M, Wilcock A. Furosemide. Journal of Pain and Symptom Management 2016; 52: 144-50.

51 Wen DL, Leuppi-Taegtmeyer Anne B, van den Anker J, Daniel T, Verena G. Prevalence of high-risk drug-drug interactions in paediatric inpatients: A retrospective, single-centre cohort analysis. Swiss Medical Weekly 2019; 149:20103.

52 Moore N, Pollack C, Butkerait P. Adverse drug reactions and drug-drug interactions with over-the-counter NSAIDs. Therapeutics and Clinical Risk Management. 2015; 11:1061-75.

53 Schmitt C, Kuhn B, Zhang X, Kivitz AJ, Grange S. Diseasedrug-drug interaction involving tocilizumab and simvastatin in patients with rheumatoid arthritis. Clinical Pharmacology and Therapeutics 2011; 89:735-40.

54 Jafari A, Dadkhahfar S, Perseh S. Considerations for interactions of drugs used for the treatment of COVID-19 with anti-cancer treatments. Critical Reviews in Oncology/Hematology. 2020; 151. DOI:10.1016/j.critrevonc.2020.102982.

55 Dashti-Khavidaki S, Khalili H. Considerations for Statin Therapy in Patients with COVID-19. Pharmacotherapy. 2020; 40:484-6.

56 Giudicessi JR, Noseworthy PA, Friedman PA, Ackerman MJ. Urgent Guidance for Navigating and Circumventing the
QTc-Prolonging and Torsadogenic Potential of Possible Pharmacotherapies for Coronavirus Disease 19 (COVID19). Mayo Clinic Proceedings 2020; 95:1213-21.

57 Ghasemiyeh P, Borhani-Haghighi A, Karimzadeh I, et al. Major neurologic adverse drug reactions, potential drugdrug interactions and pharmacokinetic aspects of drugs used in covid-19 patients with stroke: A narrative review. Therapeutics and Clinical Risk Management. 2020; 16:595-605.

58 Maus M v., Lionakis MS. Infections associated with the new "nibs and mabs" and cellular therapies. Current opinion in infectious diseases 2020; 33:281-9.

59 Antinori S, Bonazzetti C, Gubertini G, et al. Tocilizumab for cytokine storm syndrome in COVID-19 pneumonia: an increased risk for candidemia? Autoimmunity Reviews. 2020; 19. DOI:10.1016/j.autrev.2020.102564.

60 Morel J, Constantin A, Baron G, et al. Risk factors of serious infections in patients with rheumatoid arthritis treated with tocilizumab in the French Registry REGATE. Rheumatology (United Kingdom) 2017; 56: 1746-54.

61 XARELTO® (rivaroxaban): A Prescription Blood Thinner | XARELTO ® (rivaroxaban). https://www.xarelto-us.com/ (accessed Aug 26, 2020).

62 FDA. HIGHLIGHTS OF PRESCRIBING INFORMATION OF XELJANZ® (tofacitinib) tablets. 2018 https://www.accessdata.fda.gov/drugsatfda_docs/label/2 018/203214s018lbl.pdf (accessed Aug 26, 2020).

63 Shi JG, Chen X, Emm T, et al. The effect of CYP3A4 inhibition or induction on the pharmacokinetics and pharmacodynamics of orally administered ruxolitinib (INCB018424 phosphate) in healthy volunteers. Journal of Clinical Pharmacology 2012; 52:809-18.

64 Umehara K, Huth F, Jin Y, et al. Drug-drug interaction (DDI) assessments of ruxolitinib, a dual substrate of CYP3A4 and CYP2C9, using a verified physiologically based pharmacokinetic (PBPK) model to support regulatory submissions. Drug Metabolism and Personalized Therapy 2019; 34. DOI:10.1515/dmpt-2018-0042.

65 FDA. HIGHLIGHTS OF PRESCRIBING INFORMATION for JAKAFI® (ruxolitinib) tablets. 2017 https://www.accessdata.fda.gov/drugsatfda_docs/label/2 017/202192s015lbl.pdf. (accessed Aug 26, 2020).

66 FDA, cder. HIGHLIGHTS OF PRESCRIBING INFORMATION for KEVZARA (sarilumab) injection. 2017 https://www.accessdata.fda.gov/drugsatfda_docs/label/2 018/761037s001lbl.pdf (accessed Aug 26, 2020).

67 Lee EB, Daskalakis N, Xu C, et al. Disease-Drug Interaction of Sarilumab and Simvastatin in Patients with Rheumatoid Arthritis. Clinical Pharmacokinetics 2017; 56:607-15.

68 Hughes GJ, Patel PN, Saxena N. Effect of acetaminophen on international normalized ratio in patients receiving warfarin therapy. Pharmacotherapy. 2011; 31: 591-7.

69 Gebauer MG, Nyfort-Hansen K, Henschke PJ, Gallus AS. Warfarin and acetaminophen interaction.

Pharmacotherapy 2003; 23:109-12.

70 Sorkin EM, Darvey DL. Review of cimetidine drug interactions. Drug Intelligence and Clinical Pharmacy. 1983; 17: 110-20.

$71 \quad$ FDA. Cimetidine. 1998. https://www.accessdata.fda.gov/drugsatfda_docs/anda/9 8/75285_Cimetidine.pdf (accessed Aug 26, 2020).

72 A Multi-site, Randomized, Double-Blind, Comparative Trial of the Safety and Efficacy of Standard of Care (SOC) Plus Famotidine vs SOC Plus Placebo for the Treatment of COVID-19 in Hospitalized Adults. 2020; published online April 7. https://clinicaltrials.gov/ct2/show/NCT04370262 (accessed Aug 27, 2020).

73 Holbrook AM, Pereira JA, Labiris R, et al. Systematic overview of warfarin and its drug and food interactions. Archives of Internal Medicine. 2005; 165: 1095-106.

74 Fda, Cder. HIGHLIGHTS OF PRESCRIBING INFORMATION OF ASCOR (ascorbic acid). https://www.accessdata.fda.gov/drugsatfda_docs/label/2 017/209112s000lbl.pdf (accessed Aug 26, 2020).

75 Robien K, Oppeneer SJ, Kelly JA, Hamilton-Reeves JM. Drug-Vitamin D Interactions. Nutrition in Clinical Practice 2013; 28:194-208. 
76 Mousa SA. Comparative efficacy of different lowmolecular-weight heparins (LMWHs) and drug interactions with LMWH: Implications for management of vascular disorders. In: Seminars in Thrombosis and Hemostasis. Semin Thromb Hemost, 2000: 39-46.

77 Cohen M. Combination of low molecular weight heparins with antiplatelet agents in non-ST elevation acute Coronary syndromes: An update. Drugs. 2002; 62:175570.

78 FDA, cder. Innohep (tinzaparin sodium injection). https://www.accessdata.fda.gov/drugsatfda_docs/label/2 010/020484s014lbl.pdf (accessed Aug 26, 2020).

79 HIGHLIGHTS OF PRESCRIBING INFORMATION OF Lovenox (enoxaparin sodium injection) . 1993 https://www.accessdata.fda.gov/drugsatfda_docs/label/2 009/020164s085lbl.pdf (accessed Aug 26, 2020).

80 Ding Y, Jia YY, Li F, et al. The effect of staggered administration of zinc sulfate on the pharmacokinetics of oral cephalexin. British Journal of Clinical Pharmacology 2012; 73:422-7.

81 Uivarosi V. Metal complexes of quinolone antibiotics and their applications: An update. Molecules. 2013; 18:1115397.

82 Bartlett JG, Chang te W, Gurwith M, Gorbach SL, Onderdonk AB. Antibiotic-Associated Pseudomembranous Colitis Due to Toxin-Producing Clostridia. New England Journal of Medicine 1978; 298:531-4.

83 Farooq 0, Memon Z, Stojanovski SD, Faden HS. Azithromycin-induced agitation and choreoathetosis. Pediatric Neurology 2011; 44:311-3.

84 Bhattacharyya S, Darby R, Berkowitz AL. AntibioticInduced Neurotoxicity. Current Infectious Disease Reports. 2014; 16: 1-6.

85 Pradhan S, Pardasani V, Ramteke K. Azithromycininduced myasthenic crisis: Reversibility with calcium gluconate. Neurology India 2009; 57:352.

86 Chorin E, Wadhwani L, Magnani S, et al. QT interval prolongation and torsade de pointes in patients with COVID-19 treated with hydroxychloroquine/azithromycin. Heart Rhythm 2020; published online Sept 1. DOI:10.1016/j.hrthm.2020.05.014.

87 Hancox JC, Vieweg WVR, Hasnain M, Crouse ELB, Baranchuk A. Azithromycin, cardiovascular risks, QTc interval prolongation, torsade de pointes, and regulatory issues: A narrative review based on the study of case reports. Therapeutic Advances in Infectious Disease 2013; 1:155-65.

88 Herman BE, Vargo J, Phillips WS, Sweeney WB, Volpe RJ. Antibiotic-Associated Fulminant Pseudomembranous Colitis without Toxic Megacolon. The American Journal of Gastroenterology 1992; 87:1816-9.

89 FDA. ARALEN ® CHLOROQUINE PHOSPHATE, USP. 2003 https://www.accessdata.fda.gov/drugsatfda_docs/label/2 013/006002s043lbl.pdf (accessed Aug 27, 2020).

90 Vanheesbeke A. Retinal pigment epithelium--the point about safety of antimalarial agents. Bulletin de la Société belge d'ophtalmologie. 2007; 47-58.

91 Cursiefen C, Grunert U, Jünemann A. Chloroquine-induced bull's-eye maculopathy without electrophysiologic changes. Klinische Monatsblatter fur Augenheilkunde. 1997; 210:400-1.

92 Rossmann-Ringdahl I, Olsson R. Porphyria cutanea tarda: Effects and risk factors for hepatotoxicity from high-dose chloroquine treatment. Acta Dermato-Venereologica 2007; 87:401-5.

93 Fish DR, Espir MLE. Convulsions associated with prophylactic antimalarial drugs: Implications for people with epilepsy. British Medical Journal 1988; 297:526-7.

94 Benbadis SR, van Ness PC, Mulhauser P, Allemann Y, Regamey C. Chloroquine and nonconvulsive status epilepticus. Annals of Internal Medicine. 1996; 124:614-5.

95 Vestey JP, Savin JA. Psoriasis worsened by antimalarial prophylaxis. Journal of Infection. 1992; 24:211-2.

96 Balak D, Hajdarbegovic E. Drug-induced psoriasis: clinical perspectives. Psoriasis: Targets and Therapy 2017; Volume 7: 87-94.

97 Okor RS. ONSET OF PRURITOGENICITY OF CHLOROQUINE AND THE IMPLICATION FOR THE TIMING
OF SUPPRESSIVE THERAPY. Journal of Clinical Pharmacy and Therapeutics 1991; 16:463-5.

98 fda, cder. PLAQUENIL ® HYDROXYCHLOROQUINE SULFATE TABLETS, USP DESCRIPTION. https://www.accessdata.fda.gov/drugsatfda_docs/label/2 017/009768s037s045s047lbl.pdf (accessed Aug 27, 2020).

99 Sanders JM, Monogue ML, Jodlowski TZ, Cutrell JB. Pharmacologic Treatments for Coronavirus Disease 2019 (COVID-19): A Review. JAMA - Journal of the American Medical Association. 2020; 323:1824-36.

100 CDC. Avigan (favipiravir) tablets . 2017 https://www.cdc.gov.tw/File/Get/ht8jUiB_MIaKnlwstwzvw (accessed Aug 27, 2020).

101 Corbett AH, Lim ML, Kashuba ADM, Maldonado WT Larouche M. Kaletra (lopinavir/ritonavir). Annals of Pharmacotherapy 2002; 36:1193-203.

102 Pai VB, Koranyi K, Nahata MC. Acute hepatitis and bleeding possibly induced by zidovudine and ritonavir in an infant with HIV infection. Pharmacotherapy 2000; 20:1135-40.

103 Danner SA, Carr A, Leonard JM, et al. A short-term study of the safety, pharmacokinetics, and efficacy of ritonavir, an inhibitor of hiv-1 protease. New England Journal of Medicine 1995; 333:1528-34.

104 Hardy H, Esch LD, Morse GD. Glucose disorders associated with HIV and its drug therapy. Annals of Pharmacotherapy. 2001; 35:343-51.

105 Calza L, Manfredi R, Chiodo F. Insulin Resistance and Diabetes Mellitus in HIV-Infected Patients Receiving Antiretroviral Therapy. Metabolic syndrome and related disorders 2004; 2:241-50.

106 Fathallah N, Slim R, Larif S, Hmouda H, ben Salem C. Drug-Induced Hyperglycaemia and Diabetes. Drug Safety. 2015; 38:1153-68.

107 Grein J, Ohmagari N, Shin D, et al. Compassionate Use of Remdesivir for Patients with Severe Covid-19. New England Journal of Medicine 2020; 382:2327-36.

108 Administration D. FACT SHEET FOR HEALTH CARE PROVIDERS EMERGENCY USE AUTHORIZATION (EUA) OF VEKLURY $®$ (remdesivir).

https://www.fda.gov/emergency- (accessed Aug 27, 2020).

109 Ahmed O, Brahmania M, Alsahafi M, Alkhowaiter S, Erb S. Anakinra Hepatotoxicity in a Patient With Adult-Onset Still's Disease. REPORTS JOURNAL acgcasereports.gi.org ACG Case Reports Journal 2015; 2. DOI:10.14309/crj.2015.45.

110 Yang BB, Baughman S, Sullivan JT. Pharmacokinetics of anakinra in subjects with different levels of renal function. Clinical Pharmacology and Therapeutics 2003; 74:85-94.

111 Galloway JB, Hyrich KL, Mercer LK, et al. The risk of serious infections in patients receiving anakinra for rheumatoid arthritis: Results from the British Society for Rheumatology Biologics Register. Rheumatology. 2011; 50:1341-2.

112 FDA. DECADRON ® (DEXAMETHASONE TABLETS, USP). https://www.accessdata.fda.gov/drugsatfda_docs/label/2 004/11664slr062_decadron_lbl.pdf (accessed Aug 27 2020).

113 Wong V, Lefloch N, Crawford JR. Fatal gastrointestina hemorrhage in a young boy with newly diagnosed metastatic medulloblastoma on high dose dexamethasone. Case reports in pediatrics 2014; 2014:478326.

114 Fadul CE, Lemann W, Thaler HT, Posner JB. Perforation of the gastrointestinal tract in patients receiving steroids for neurologic disease. Neurology 1988; 38:348-52.

115 DeMaria EJ, Reichman W, Kenney PR, Armitage JM, Gann DS. Septic complications of corticosteroid administration after central nervous system trauma. Annals of Surgery 1985; 202:248-52.

116 Carrel TP, Schaffner A, Schmid ER, et al. Fatal fungal pericarditis after cardiac surgery and immunosuppression | Aspergillus \& Aspergillosis Website. J Thorac Cardiovasc Surg 1991; 101:161-4

117 Ludvik B, Clodi M, Kautzky-Willer A, et al. Effect of dexamethasone on insulin sensitivity, islet amyloid 
polypeptide and insulin secretion in humans. Diabetologia 1993; 36:84-7.

118 CUNLIFFE WJ, BURTON JL, HOLTI G, WRIGHT V. Hazards of steroid therapy in hepatic failure. British Journal of Dermatology 1975; 93:183-5.

119 Coloma PM, Schuemie MJ, Trifirò G, et al. Drug-Induced Acute Myocardial Infarction: Identifying "Prime Suspects" from Electronic Healthcare Records-Based Surveillance System. PLoS ONE 2013; 8. DOI:10.1371/journal.pone.0072148.

120 Shokr M, Rashed A, Lata K, Kondur A. Dexamethasone Associated ST Elevation Myocardial Infarction Four Days after an Unremarkable Coronary Angiogram-Another Reason for Cautious Use of Steroids: A Case Report and Review of the Literature. Case Reports in Cardiology 2016; 2016:1-6.

121 Varas-Lorenzo C, Rodriguez LAG, Maguire A, Castellsague J, Perez-Gutthann S. Use of oral corticosteroids and the risk of acute myocardial infarction. Atherosclerosis 2007; 192:376-83.

122 Dele Davies H. Infectious complications with the use of biologic response modifiers in infants and children. Pediatrics 2016; 138. DOI:10.1542/peds.2016-1209.

123 Drepper M, Rubbia-Brandt L, Spahr L. TocilizumabInduced Acute Liver Injury in Adult Onset Still's Disease. Case Reports in Hepatology 2013; 2013:1-3.

124 Lussana F, Cattaneo M, Rambaldi A, Squizzato A. Ruxolitinib-associated infections: A systematic review and meta-analysis. American Journal of Hematology 2018; 93:339-47.

125 Sylvine P, Thomas S, Pirayeh E. Infections associated with ruxolitinib: study in the French Pharmacovigilance database. Annals of Hematology. 2018; 97:913-4.

126 Fleischmann R, Genovese MC, Lin Y, et al. Long-term safety of sarilumab in rheumatoid arthritis: an integrated analysis with up to 7 years' follow-up. Rheumatology (Oxford, England) 2020; 59:292-302.

127 Yoon E, Babar A, Choudhary M, Kutner M, Pyrsopoulos N. Acetaminophen-Induced Hepatotoxicity: a Comprehensive Update. Journal of Clinical and Translational Hepatology 2016; 4:131.

128 Inotsume N, Nishimura M, Fujiyama S, et al. Pharmacokinetics of famotidine in elderly patients with and without renal insufficiency and in healthy young volunteers. European Journal of Clinical Pharmacology 1989; 36:517-20.

129 Lin JH, Chremos AN, Yeh KC, Antonello J, Hessey GA. Effects of age and chronic renal failure on the urinary excretion kinetics of famotidine in man. European Journal of Clinical Pharmacology 1988; 34:41-6.

130 Halstenson CE, Abraham PA, Opsahl JA, Chremos AN Keane WF, Matzke GR. Disposition of Famotidine in Renal Insufficiency. The Journal of Clinical Pharmacology 1987; 27:782-7.

131 Quinn J, Gerber B, Fouche R, Kenyon K, Blom Z, Muthukanagaraj P. Effect of High-Dose Vitamin C Infusion in a Glucose-6-Phosphate Dehydrogenase-Deficient Patient. Case Reports in Medicine 2017; 2017. DOI:10.1155/2017/5202606.

132 Liu X, Wang W, Tan Z, et al. The relationship between vitamin $\mathrm{D}$ and risk of atrial fibrillation: A dose-response analysis of observational studies. Nutrition Journal. 2019; 18:73.

133 Moe SM. Disorders Involving Calcium, Phosphorus, and Magnesium. Primary Care - Clinics in Office Practice. 2008; 35:215-37.

134 Michos ED, Blumenthal RS. Vitamin D supplementation and cardiovascular disease risk. Circulation. 2007; 115:827-8
135 Hippensteel JA, LaRiviere WB, Colbert JF, LangouëtAstrié CJ, Schmidt EP. Heparin as a therapy for COVID-19: current evidence and future possibilities. American journal of physiology. Lung cellular and molecular physiology. 2020; 319:L211-7.

136 Míka P, Běhounek J, Skoták M, Nevšímal L. Complications and risks associated with an anticoagulation therapy combining low molecular weight heparin and warfarin after total replacement of large joints - Our experience. Acta Chirurgiae Orthopaedicae et Traumatologiae Cechoslovaca 2004; 71:237-44.

137 FDA, cder. HIGHLIGHTS OF PRESCRIBING INFORMATION of HEPARIN SODIUM IN SODIUM CHLORIDE INJECTION. 2019

https://www.accessdata.fda.gov/drugsatfda_docs/label/2 019/018916s063,019339s052,019805s034lbl.pdf (accessed Aug 26, 2020).

138 Medicine I of. Dietary Reference Intakes for Vitamin A, Vitamin K, Arsenic, Boron, Chromium, Copper, Iodine, Iron, Manganese, Molybdenum, Nickel, Silicon, Vanadium, and Zinc. National Academies Press, 2001 DOI:10.17226/10026.

139 Freeland-Graves JH, Friedman BJ, Wu-Hsin Han, Shorey RL, Young R. Effect of zinc supplementation on plasma high-density lipoprotein cholesterol and zinc. American Journal of Clinical Nutrition 1982; 35:988-92.

140 Johnson AR, Munoz A, Gottlieb JL, Jarrard DF. High Dose Zinc Increases Hospital Admissions Due to Genitourinary Complications. Journal of Urology 2007; 177: 639-43.

141 Lewis MR, Kokan L. Zinc Gluconate: Acute Ingestion. Journal of Toxicology - Clinical Toxicology 1998; 36:99-101.

142 Pharmacology JS-B, 2008 undefined. A global view of drug-therapy interactions. search.ebscohost.com http://search.ebscohost.com/login.aspx?direct=true\&profi le=ehost $\&$ scope $=$ site \&authtype $=$ crawler $\&$ jrnl $=14712210 \&$ $\mathrm{AN}=35702595 \& \mathrm{~h}=\mathrm{iFyoITy} \% 2 \mathrm{BpS} 8 \mathrm{pw} 9 \% 2 \mathrm{BxKQ81} \% 2 \mathrm{~F} \% 2$ FJ42vVqmcepe65Fijj7E1EDWjhv\%2BcaKcdtXvSK7TdOQl \%2BPVGpwPEXy9hsyNsq3\%2FPg\%3D\%3D\&crl=c (accessed Aug 25, 2020).

143 Palleria C, Paolo A di, Giofrè C, ... CC-J of research in, 2013 undefined. Pharmacokinetic drug-drug interaction and their implication in clinical management. ncbi.nlm.nih.gov https://www.ncbi.nlm.nih.gov/pmc/articles/PMC389702 9/ (accessed Aug 25, 2020).

144 Lorenzo G di, Trolio R di, Kozlakidis Z, ... GB-CR in, 2020 undefined. COVID 19 therapies and anti-cancer drugs: A systematic review of recent literature. Elsevier https://www.sciencedirect.com/science/article/pii/S104 0842820301293 (accessed Aug 25, 2020).

145 Sanders J, Monogue M, Jodlowski T, Jama JC-, 2020 undefined. Pharmacologic treatments for coronavirus disease 2019 (COVID-19): a review. jamanetwork.com https://jamanetwork.com/journals/jama/articleabstract/2764727 (accessed Aug 25, 2020).

146 Swapna G, Pravallika B, Poojitha J. A Review on Drugdrug interaction studies on Amiodarone and Levofloxacin. Research Journal of Pharmacology and Pharmacodynamics 2019; 11:147.

147 Radhwan N. Al-Zidan, Ahmed S. Saadallah, Ghayth M Abdulrazzaq. The public health dilemma of Self-Medication with Antibiotics: The undergraduate students of the College of Pharmacy in Mosul as an example. International Journal of Research in Pharmaceutical Sciences 2020; 11:3743-51.

148 Rabie MMed Paed H, Denti P, McIlleron H, et al. Lopinavir-ritonavir super-boosting in young HIV-infected children on rifampicin-based tuberculosis therapy compared with lopinavir-ritonavir without rifampicin: a pharmacokinetic modelling and clinical study. 2018. DOI:10.1016/S2352-3018(18)30293-5. 